Rebut: 30 d'octubre de 2019

\title{
RELACIÓ ENTRE MICROBIOTA INTESTINAL, INFLAMACIÓ I ENVELLIMENT
}

\author{
TORNER GRIMA, CARLES ${ }^{1}$ \\ Departament de Biologia, Sanitat i Medi Ambient \\ Secció departamental de Microbiologia \\ Facultat de Farmàcia, Universitat de Barcelona, \\ Av. Joan XXIII, s/n, 08028 Barcelona
}

\begin{abstract}
Gut microbiota is changing constantly from birth to death, and in a similar way for most of the population. Common lifestyle habits of elderly people affect how it changes, and the new composition of microbiota in old age contributes to greater systemic inflammation, which accelerates the aging process andage-associated diseases. This paper examines the evidence available to this day on gut microbiota changes in old people and centenarians. It then considers the differences between both groups, with the aim of understanding why centenarians live longer. Finally, based on the information obtained, some of the products currently available on the market are examined to determine if they could be prescribed to improve the health of elderly people, and an ideal probiotic product for healthy aging is proposed.
\end{abstract}

Keywords: gut microbiota, inflammation, aging, probiotic

\section{Resumen}

La microbiota intestinal experimenta cambios desde el nacimiento hasta la muerte, de forma parecida en la mayoría de la población. En personas de edad avanzada, este cambio se ve favorecido por variaciones en el estilo de vida. Además, esta nueva microbiota en la vejez se relaciona con una mayor inflamación sistémica, la cual puede acelerar el proceso de envejecimiento y la aparición de enfermedades asociadas.

Este trabajo recopila las evidencias bibliográficas disponibles hasta el momento sobre los cambios de la microbiota intestinal en personas de edad avanzada y centenaria. A partir de aquí, se hace una reflexión sobre las diferencias entre los dos grupos con el objetivo de conocer por qué los centenarios viven más años. Finalmente, con la información obtenida, se estudia si probióticos comercializados actualmente se podrían prescribir para mejorar la salud en edad avanzada y, asimismo, se propone un probiótico que sería idóneo para un envejecimiento saludable.

Palabras clave: microbiota intestinal, inflamación, envejecimiento, probiótico.

\section{Resum}

La microbiota intestinal va experimentant canvis des del naixement fins a la mort, de manera similar a gran part de la població. En persones d'edat avançada, variacions en l'estil de vida afavoreixen aquest canvi en la composició de la microbiota. A més, aquesta nova microbiota es relaciona amb major inflamació sistèmica, que al seu torn accelera el procés d'envelliment $\mathrm{i}$ les malalties associades.

Aquest treball recopila les evidències disponibles fins ara sobre els canvis de la microbiota intestinal en persones d'edat avançada i centenàries. A partir d'aquí, es fa una reflexió sobre les diferències entre els dos grups, amb l'objectiu de conèixer per què les persones centenàries viuen més anys. Finalment, partint de la informació obtinguda, s'estudia si es podrien prescriure probiòtics comercialitzats per a la millora de la salut en edat avançada i es proposa un probiòtic que podria ser l'idoni per a un envelliment saludable.

Paraules clau: microbiota intestinal, inflamació, envelliment, probiòtic.

\footnotetext{
${ }^{1}$ Graduat en Farmàcia (ctornegr7@alumnes.ub.edu).
} 


\section{Introducció}

\subsection{Què és la microbiota?}

Aquest treball se centrarà en la relació de la microbiota amb l'edat. Per tant, a què es refereix el terme microbiota? Fa referència al conjunt de microorganismes, sobretot bacteris, que habiten en l'ésser humà de manera simbiòtica, comensal o patogènica (Clemente, Manasson i Scher, 2018). Estudis recents (Sender, Fuchs i Milo, 2016) suggereixen que la relació dels bacteris respecte a les cèl-lules humanes és més aviat 1:1, és a dir, posen en dubte la relació 10:1 a favor dels bacteris utilitzada fins ara.

Es pot parlar de microbiota intestinal, oral, vaginal, tòpica... No obstant això, el treball se centrarà únicament en l'estudi de la més abundant: la microbiota intestinal. Aquesta està integrada per més de cent bilions de microorganismes, entre els quals s'inclouen més de mil espècies de bacteris coneguts (Buford, 2017).

Cal diferenciar el concepte de microbiota del de microbioma, que fa referència al conjunt de tots els gens que componen la microbiota d'un ésser viu (Clemente, Manasson i Scher, 2018).

\subsection{Com es classifiquen taxonòmicament els bacteris?}

Com que el treball tracta dels bacteris, és important fer un breu incís sobre la seva classificació i nomenclatura. La informació d'aquest apartat s'ha extret del llibre Brock. Biologia dels microorganismes (Madigan et al., 2015).

Pel que fa a la classificació, segueix la seqüència següent:

$$
\text { Espècie < gènere < família < ordre < classe < fílum < domini (Bacteria) }
$$

La nomenclatura utilitzada segueix el sistema binominal ideat pel botànic suec Carl Linneo, segons el qual els organismes s'anomenen mitjançant el gènere i l'adjectiu de l'espècie. Els noms són en llatí o en derivacions de grec llatinitzat.

\subsection{Quins són els fílums predominants a l'intestí?}

Centrant més l'atenció en la microbiota intestinal, es pot acotar el domini Bacteria i parlar especialment dels fílums principals que componen aquesta microbiota. Sovint el tracte gastrointestinal es veu com un sistema de dos fílums, el Firmicutes i el Bacteroidetes (els dos junts en componen $>90 \%$ ), però també hi ha representació de fílums com Proteobacteria (relativament abundant), Actinobacteria, Fusobacteria o Verrucomicrobia (RoblesAlonso i Guarner, 2013).

\subsection{Què s'entén per inflammaging?}

Sortint de les generalitats sobre la microbiota intestinal, el treball se centra en la relació que hi ha entre aquesta i el concepte d'inflammaging.

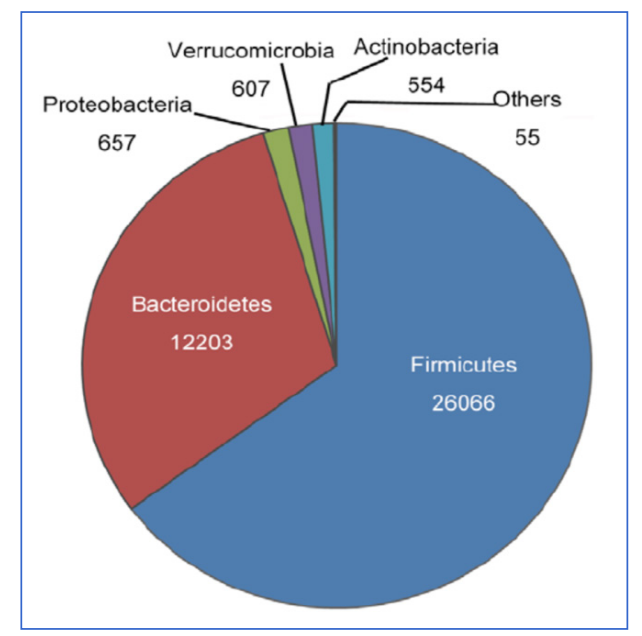

Figura 1. Representació gràfica que mostra un exemple de les proporcions dels diferents fílums presents en la microbiota intestinal. S'observa el clar predomini de Firmicutes i Bacteroidetes. Imatge extreta de l'article de Yang i els seus colllaboradors (Yang et al., 2009). 
Així, doncs, què és el que s'anomena inflammaging? Com es pot deduir de la paraula anglesa, el terme uneix dos conceptes, inflammation i aging, és a dir, la inflamació i l'envelliment. Per tant, es podria definir com la inflamació crònica de baix grau que va junta amb l'envelliment de l'esser humà (Franceschi i Campisi, 2014; Calder et al., 2017).

Es creu que hi ha diferents factors responsables d'aquest augment de la inflamació a mesura que augmenten els anys (Franceschi i Campisi, 2014; Calder et al., 2017), alguns dels quals són:

- Macromolècules i cèlllules danyades acumulades amb l'edat, a causa d'un augment de la seva producció o d'una eliminació inadequada.

- Senescència celllular, és a dir, envelliment de les cèlllules en resposta al dany i a l'estrès.

- Increment de l'activació del sistema de coagulació que té lloc amb l'edat.

- Canvis en el sistema immunitari que afavoreixen l'inflammaging.

- Regulació deficient o inapropiada del sistema del complement.

- Canvis en la microbiota i pèrdua de la capacitat de l'intestí de segrestar els microbis o els seus metabòlits.

Així, doncs, el canvi que es presenta en la microbiota és un dels factors que s'ha relacionat amb un augment de la inflamació. Al seu torn, com es veurà a continuació, un augment de la inflamació també s'associa amb un envelliment precoç.

\subsection{Nexe entre microbiota i inflammaging}

Com s'ha dit, la microbiota intestinal i el seu genoma tenen una gran representació quantitativa respecte a les cèlllules eucariotes humanes. És per això que el 70\% dels limfòcits de l'hoste resideixen en el teixit limfoide associat al tracte gastrointestinal, amb l'objectiu de mantenir l'homeòstasi amb la microbiota (Buford, 2017). Aquesta elevada proporció de limfòcits interaccionant amb els bacteris intestinals ja deixa entreveure la gran relació que pot tenir amb la inflamació.

Per tant, la microbiota està molt relacionada amb la inflamació local intestinal, així com amb les reaccions immunitàries que hi tenen lloc. Com exposa Buford en la seva revisió (Buford, 2017), la microbiota és clau respecte a la tolerància al menjar i als al-lèrgens que entren per via oral. També té un paper protector en la inflamació aguda, ja que activa els receptors de tipus Toll (toll-like receptors, TLR) i promou la reparació tissular (Buford, 2017). A més a més, hi ha soques que produeixen àcids grassos de cadena curta a partir de fibra. Aquests àcids grassos serveixen d'energia per a les cèlllules epitelials i tenen una acció antiinflamatòria, ja que inhibeixen les histones desacetilases en les cèllules T reguladores, mitjançant un receptor acoblat a proteïna G (Clemente, Manasson i Scher, 2018).

És cert que, avui dia, està àmpliament acceptat $i$ estudiat que la microbiota pot tenir un paper important en la inflamació local intestinal. Tot i això, l'evidència del rol que té en el control de la inflamació i la immunitat en òrgans allunyats del tracte intestinal també augmenta (Belkaid i Hand, 2014).

Complementàriament, es van observant soques de bacteris, com alguna soca de Clostridium, que mostren propietats antiinflamatòries, atès que indueixen citosines antiinflamatòries com les ilodecakines (IL-10) i limfòcits T reguladors (Zapata i Quagliarello, 2015).

Hi ha tantes microbiotes intestinals diferents en els éssers humans com éssers humans existents. Per això sovint s'utilitzen sistemes per simplificar i poder classificar les persones en funció de la seva microbiota (Van de Guchte, Blottière i Doré, 2018). Una d'aquestes classificacions es basa en diversos enterotips establerts segons els grups de bacteris predominants, utilitzant la ràtio Prevotella / (Bacteroides + Prevotella). En aquest cas, l'enterotip Prevotella s'associa a una dieta alta en fibra, rica en fruita i vegetals. En canvi, l'enterotip Bacteroides està lligat a una dieta amb un alt consum de greix animal i proteïnes.

Paral-lelament, també es pot trobar la classificació en funció de la «riquesa genètica», la qual mesura la diversitat de la microbiota a partir d'una mostra. S'observen ràpidament dos grups: un 
microbioma amb «recompte de gens Baix» (low gene count, LGC) i un altre amb «recompte de gens alt» (high gene count, HGC). Casualment, per norma general els hostes amb un recompte de gens baix, és a dir, amb poca diversitat de bacteris, coincideixen amb l'enterotip Bacteroides. Al seu torn, els hostes amb aquest enterotip són més propensos a desenvolupar obesitat, resistència a la insulina, alteracions dels lípids i un fenotip més inflamatori respecte a l'enterotip Prevotella (Van de Guchte, Blottière i Doré, 2018).

Queda clara, doncs, la relació de la microbiota amb una propensió major o menor a la inflamació sistèmica. És important tenir clar que la microbiota no és estàtica i, per tant, es pot passar d'un enterotip a un altre (Van de Guchte, Blottière i Doré, 2018).

\subsection{Inflamació com a accelerador de l'envelliment}

L'evidència sobre el rol que té la microbiota en la inflamació crònica associada a l'edat ha anat augmentant. Paral-lelament, gràcies a les noves tècniques de seqüenciació massiva s'ha anat veient que la microbiota varia en funció de l'edat. La gent gran sovint pateix comorbiditats intestinals, canvis en la dieta o en l'activitat física diària, així com altres canvis fisiològics que poden propiciaralteracions en la microbiota intestinal. Aquesta modificació que té lloc s'ha relacionat amb l'augment de la inflamació sistèmica crònica (Buford, 2017).

Dit això, què entenem per envelliment? L'envelliment es pot definir com un procés inevitable, universal i complex, caracteritzat per una pèrdua progressiva de la funcionalitat i la capacitat d'adaptació a l'entorn (Minciullo et al., 2016).

Curiosament, es creu que l'envelliment i la gran majoria de les malalties associades a l'edat, si bé no totes, comparteixen una patogènesi inflamatòria (Franceschi i Campisi, 2014). Hi ha diferents estudis que associen la inflamació amb l'envelliment, però en què es basen per afirmar-ho?

La inflamació aguda és un procés fisiològic que ajuda a la reparació, regeneració i adaptació dels teixits en situacions adverses, com és el cas de traumatismes, lesions o infeccions (Franceschi i Campisi, 2014). Ara bé, amb l'edat es va perdent la capacitat de resoldre aquesta inflamació aguda, de manera que els leucòcits continuen infiltrant-se al teixit, alliberant citosines inflamatòries i desenvolupant una inflamació crònica (Franceschi i Campisi, 2014).

Això explicaria que en persones d'edat avançada i en absència d'inflamació aguda es trobin nivells més elevats de mediadors que afavoreixen la inflamació. Per exemple, presenten valors superiors d'interleucina-6 (IL-6), de proteïna C reactiva (CRP) o de factor de necrosi tumoral alfa (TNF- $\alpha$ ) (Buford, 2017). Aquesta inflamació crònica s'ha relacionat amb un gran ventall de comorbiditats associades a l'edat, com ara malalties cardiovasculars, osteoporosi, declivi cognitiu o demència, fragilitat $\mathrm{o}$ debilitat, sarcopènia, diabetis de tipus II, càncer, asma, celiaquia artritis entre altres.

Per tant, la inflamació sistèmica crònica té un paper important en la gran majoria de malalties associades a l'edat i, consegüentment, es tracta d'un factor de risc en la població d'edat avançada (Franceschi i Campisi, 2014). El problema és que la inflamació crònica comparteix moltes característiques amb la inflamació aguda, però com que és sostinguda en el temps va portant els teixits cap al dany i la degeneració (Franceschi i Campisi, 2014).

Val a dir que les persones centenàries (que viuen més de cent anys) també mostren senyals d'inflamació sistèmica crònica, menys mecanismes antioxidants i un estat de la coagulació incrementat, típics de l'envelliment (Franceschi i Campisi, 2014). Això també deixa entreveure que la inflamació i l'augment de la coagulació són estats compatibles amb un suposat envelliment saludable. Ara bé, es creu que les persones centenàries disposen de millors respostes antiinflamatòries (per exemple, a causa de variants genètiques), que els permeten contrarestar la inflamació crònica i convertir-la en una inflamació més adaptativa. Aquesta capacitat es coneix com a anti-inflammaging (Franceschi i Campisi, 2014).

Una de les maneres d'estudiar la inflamació és a partir de les citosines, que són, en última instància, l'expressió d'una xarxa de gens, polimorfismes i ecosistemes com la microbiota intestinal (Minciullo et al., 2016). 
Es pot parlar de citosines inflamatòries (per exemple, IL-1, IL-2, IL-6, IL-12, IL-15, IL-18, IL-22, IL-23, TNF- $\alpha$, IFN-c), d'antiinflamatòries (IL-1Ra, IL-4, IL-10, TGF-b1) i dels seus mediadors (lipoxina A4, capaç d'inhibir la inflamació dependent de leucòcits, i proteïnes de xoc tèrmic, que estimulen l'alliberació de citosines inflamatòries) (Minciullo et al., 2016).

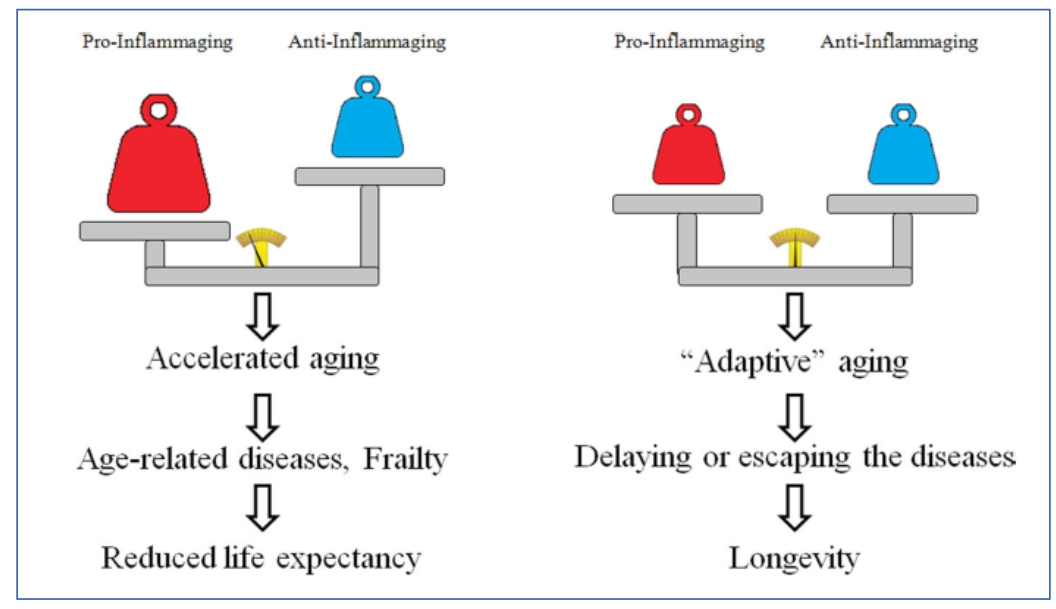

Figura 2. Esquema de l'efecte de les citosines sobre l'esperança de vida. Una representació més alta de citosines inflamatòries accelera l'envelliment, les malalties associades i l'estat de debilitat, i redueix l'esperança de vida. En canvi, un equilibri entre les citosines inflamatòries i les antiinflamatòries promou un envelliment més adaptatiu, retarda o evita l'aparició de comorbiditats i allarga l'esperança de vida. Imatge extreta de la revisió elaborada per Minciullo i els seus col-laboradors (Minciullo et al., 2016).

Hi ha una revisió molt interessant (Vaiserman, Koliada i Marotta, 2017) que recull un seguit d'estudis en els quals s'exposen efectes positius que pot presentar la microbiota envers la inflamació. Al seu torn, aquests efectes afavoreixen un envelliment saludable. Tal com diu aquesta revisió, la microbiota:

- Pot millorar la resposta immunitària adaptativa, fent front al deteriorament natural del sistema immunitari.

- Degrada carbohidrats no digeribles, fet que genera àcids grassos de cadena curta.

- Pot millorar l'activitat antioxidant.

- Participa en la producció de vitamines B i d'àcid linoleic conjugat.

- Regula la deposició de lípids.

- Participa a prevenir la resistència a la insulina.

- Millora el manteniment de la integritat de les mucoses i l'homeòstasi del sistema immunitari.

Això provoca una millora de la funció de la barrera intestinal, alhora que colllabora en la regulació de gens involucrats en el metabolisme de xenobiòtics. Tots aquests fets es tradueixen en una reducció de la inflamació i, consegüentment, en la prevenció de les malalties associades (Vaiserman, Koliada i Marotta, 2017).

Per contra, els canvis en la microbiota poden donar lloc a un augment de la permeabilitat intestinal, la qual al seu torn farà més fàcil el pas de lipopolisacàrids (LPS) cap a la circulació sistèmica. Això provocarà una toxèmia crònica de baix grau i l'activació de processos inflamatoris (Calder et al., 2017). 


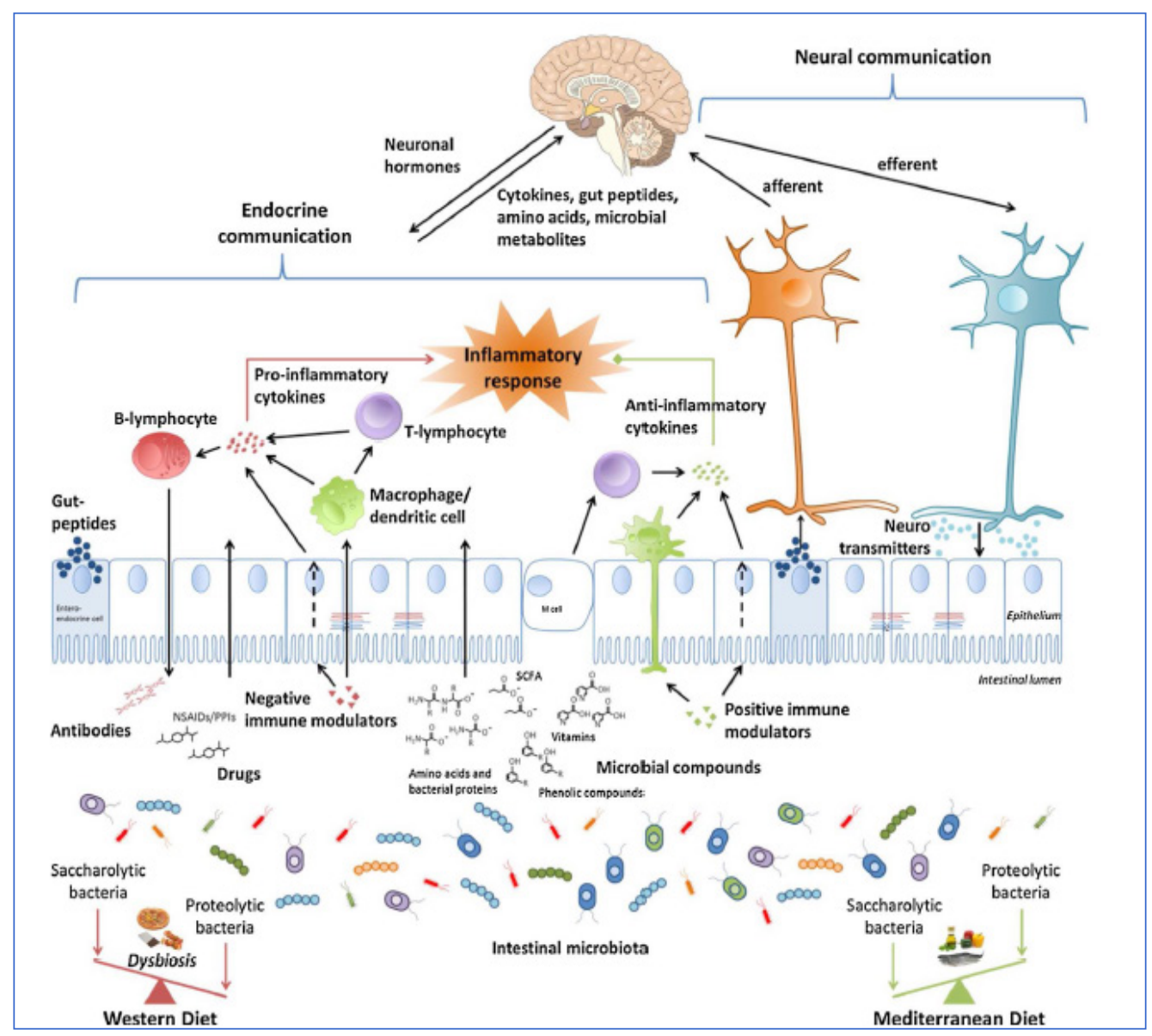

Figura 3. S'observen de manera esquemàtica els diferents mecanismes pels quals la microbiota afecta l'epiteli intestinal, la inflamació local i sistèmica, i el seu efecte al cervell. S'hi veuen representats la microbiota, les cèlllules epitelials i les cèlllules del sistema immunitari, íntimament relacionades entre si i amb les neurones del sistema nerviós. També es fa una comparativa entre la dieta mediterrània, la qual afavoreix la presència de bacteris antiinflamatoris, i una dieta de l'oest, rica en greixos, la qual propicia una disbiosi inflamatòria. Imatge extreta d'Ageing Research Reviews (Calder et al., 2017).

\section{Objectius}

Atès l'interès actual en els estudis de la microbiota intestinal humana i la seva relació amb la salut i amb diverses malalties inflamatòries, l'objectiu general del treball de fi de grau que es presenta és aprofundir en la relació entre la microbiota, el procés d'inflamació i el procés d'envelliment.

Amb aquesta finalitat, els objectius concrets del treball són:

- Fer una revisió de l'evidència publicada fins al dia d'avui sobre la relació entre microbiota, inflamació sistèmica i envelliment.

- Analitzar comparativament les diferències entre la microbiota de la població estàndard d'edat avançada, respecte a la de les persones que viuen més de cent anys.

- Indagar sobre el possible potencial de la microbiota en la prevenció de malalties associades a l'edat.

- Avaluar la utilitat de dos productes probiòtics comercialitzats per a altres indicacions, per millorar el procés d'envelliment.

- Proposar un possible complement probiòtic idoni per millorar el procés d'envelliment. 


\section{Materials i mètodes}

La metodologia utilitzada per realitzar el treball ha estat principalment la recerca bibliogràfica. S'ha consultat una gran quantitat d'articles i revisions científiques per tal de recopilar el màxim d'evidències publicades sobre el tema, així com llibres per revisar conceptes més bàsics.

Per tal de trobar la informació s'han utilitzat bases de dades com ara PubMed, Scopus, Medline i GoogleScholar. L'avantatge que han presentat tant Scopus com GoogleScholar és que en la mateixa cerca indiquen el nombre de citacions de l'article, fet que ajuda a interpretar la repercussió de l'article en la comunitat científica. A més a més, en tots els casos s'ha utilitzat el factor d'impacte, buscat a través de la base de dades de Journal Citation Reports (JCR), per avaluar la fiabilitat de la font.

Algunes de les revistes consultades han estat Microbiome, Cell, BMC Microbiology o British Medical Journal, entre d'altres, amb alts factors d'impacte.

La sistemàtica seguida ha estat sobretot la consulta de revisions i, quan s'ha trobat algun tema específic que era necessari abordar, la recerca i la lectura dels articles concrets en els quals es tocava el tema en qüestió. Els articles específics han estat principalment d'estudis experimentals sobre la microbiota de poblacions determinades, a partir dels quals es podia extreure informació concloent.

El treball s'ha complementat amb la recerca d'estudis clínics realitzats de complements probiòtics comercialitzats. Aquests estudis s'han trobat també en bases de dades com ara PubMed.

Les paraules clau més utilitzades per a la recerca han estat: microbiota intestinal, inflamació, envelliment, inflammaging, malalties inflamatòries i centenaris.

\section{Desenvolupament del treball i discussió}

\subsection{Edat avançada i població centenària}

\subsubsection{Hi ha diferències en la seva microbiota intestinal?}

Per donar resposta a aquesta pregunta s'ha fet una recerca d'un seguit de revisions: C. Bischoff, 2016; Mello et al., 2016; Calder et al., 2017; Vaiserman, Koliada i Marotta, 2017; O'Toole i Jeffery, 2018diversity and functional features of intestinal microbiota are well-described in the modern literature. They are suggested to be caused by an age-related decline in immune system functioning (immunosenescence. Aquestes, al seu torn, reuneixen els resultats de diversos estudis diferents i permeten disposar d'una visió molt àmplia i exhaustiva. Com que es tracta de revisions, la gran majoria dels punts que s'exposen a continuació pertanyen a estudis concrets que es troben citats al llarg de les revisions en qüestió.

Així, doncs, respecte a les modificacions de la microbiota en edat avançada, a nivell general la població estàndard experimenta els canvis següents:

- Reducció de la diversitat de la microbiota intestinal (Vaiserman, Koliada i Marotta, 2017). Estudis més recents relacionen la disminució de diversitat amb la pèrdua de la salut de la persona, no obligatòriament lligada a l'edat (O’Toole i Jeffery, 2018).

- L'estabilitat de la microbiota queda compromesa (Calder et al., 2017).

- Reducció de bacteris sacarolítics (Vaiserman, Koliada i Marotta, 2017).

- Augment de bacteris proteolítics (Vaiserman, Koliada i Marotta, 2017).

- Augment de bacteris amb gens capaços de metabolitzar el triptòfan (C. Bischoff, 2016).

- Reducció de les espècies dominants i increment de les subdominants (Vaiserman, Koliada i Marotta, 2017).

A més a més, s'observa un augment de:

- Fílums com Proteobacteria i Bacteroidetes (Mello et al., 2016; Vaiserman, Koliada i Marotta, 2017; O’Toole i Jeffery, 2018). 
- Gèneres com Enterococcus spp. (C. Bischoff, 2016).

- Pathobionts: concepte (en anglès) que fa referència a patògens oportunistes que estan presents en la microbiota i que augmenten en l'edat avançada (Vaiserman, Koliada i Marotta, 2017). Algunes de les famílies on es troben pathobionts són:

- Enterobacteriaceae (Vaiserman, Koliada i Marotta, 2017): inclou espècies com ara Escherichia coli (C. Bischoff, 2016).

- Enterococcaceae (Santoro et al., 2018).

- Staphylococcaceae (Santoro et al., 2018).

- Altres gèneres que s'han relacionat amb l'edat, la debilitat i la poca diversitat bacteriana:

- Desulfovibrio, del fílum Proteobacteria (Jeffery, Lynch i O’Toole, 2016).

- Coprobacillus i Anaerotruncus, del fílum Firmicutes (Jeffery, Lynch i O’Toole, 2016).

Per contra, s'observa una reducció de:

- Fílums com Firmicutes (Vaiserman, Koliada i Marotta, 2017).

- Gèneres com:

- Lactobacillus (C. Bischoff, 2016).

- Bifidobacterium: hi ha estudis (Vaiserman, Koliada i Marotta, 2017) que apunten una reducció que va del $90 \%$ en els nadons alimentats amb llet materna al 5\% en els adults, i la proporció encara disminueix més en les persones grans i amb patologies associades a l'edat.

- Clostridium del grup XIV (Vaiserman, Koliada i Marotta, 2017).

- Espècies com:

- Faecalibacterium prausnitzii: aquesta espècie és sovint un indicador de salut intestinal, ja que creix molt bé en el pH àcid d'un intestí sa (Vaiserman, Koliada i Marotta, 2017). A més a més, com hem vist, produeix butirat i també substàncies antiinflamatòries com el salicilat.

- Blautia coccoides (Vaiserman, Koliada i Marotta, 2017).

- Eubacterium rectale (Vaiserman, Koliada i Marotta, 2017).

TAULA 1. RESUM DE LES MODIFICACIONS OBSERVADES EN LA MICROBIOTA DE LA POBLACIÓ D’EDAT AVANÇADA.

\begin{tabular}{|c|c|c|c|}
\hline Firmicutes & Bacteroidetes & Proteobacteria & Actinobacteria \\
\hline $\begin{array}{l}\text { Famílies: } \\
\text { Enteroccaceae } \\
\text { Staphylococcaceae } \\
\text { Gèneres: } \\
\text { Enterococcus } \\
\text { Coprobacillus } \\
\text { Anaerotruncus }\end{array}$ & $\uparrow G e n e r a l$ del fílum & $\begin{array}{l}\uparrow \text { General del fílum } \\
\text { Família: } \\
\text { Enterobacteriaceae } \\
\text { Espècies: } \\
\text { Escherichia coli } \\
\text { Desulfovibrio }\end{array}$ & \\
\hline $\begin{array}{l}\downarrow \text { General del fílum } \\
\text { Gèneres: } \\
\text { Lactobacillus } \\
\text { Clostridium (grup XIV) } \\
\text { Espècies: } \\
\text { Faecalibacterium } \\
\text { prausnitzii } \\
\text { Blautia coccoides } \\
\text { Eubacterium rectale }\end{array}$ & & & $\begin{array}{l}\text { Gènere: } \\
\quad \text { Bifidobacterium }\end{array}$ \\
\hline
\end{tabular}


Ara bé, després de veure les modificacions que tenen lloc en la població estàndard, és interessant observar també quins canvis pateixen, per algun motiu, les persones queviuen més de cent anys. Aquestes persones reben el nom de centenàries.

Diferents troballes en aquest grup poblacional de persones centenàries apunten que:

- Presenten sovint un increment de la diversitat de la microbiotica intestinal. Alhora que els grups de bacteris principals es redueixen, aquests subjectes s'enriqueixen amb nous grups de bacteris, fins i tot amb alguns considerats pathobionts, de manera que desenvolupen un nou equilibri de l'ecosistema similar al dels humans ancestrals (Santoro et al., 2018).

També, en funció de l'estudi, s'observa en persones centenàries un augment de:

- Fílums com Proteobacteria (Vaiserman, Koliada i Marotta, 2017).

- Classes com Bacilli (Claesson et al., 2012).

- Anaerobis facultatius (Mello et al., 2016)

- Productors de butirat, com Clostridium spp. (Vaiserman, Koliada i Marotta, 2017), Eubacteriumlimosum (C. Bischoff, 2016) i Anaerotruncus colihominis (Santoro et al., 2018).

Per altra banda, les persones centenàries mostren una reducció de:

- Famílies com Enterobacteriaceae (Vaiserman, Koliada i Marotta, 2017).

- Gèneres com Bacteroides i Bifidobacterium (Vaiserman, Koliada i Marotta, 2017).

- Productors de butirat, com ara Faecalibacterium prausnitzii (C. Bischoff, 2016; Vaiserman, Koliada i Marotta, 2017; Santoro et al., 2018), Ruminococcus obeum, Roseburia intestinalis, Eubacterium ventriosum, Eubacterium rectale, Eubacterium hallii o Papillibacter cinnamovorans (Santoro et al., 2018).

A partir dels estudis amb persones amb longevitat elevada s'ha observat que moltes d'elles comparteixen un seguit de bacteris en més proporció. Aquest fet ha permès identificar un seguit d'espècies que es relacionen amb una major esperança de vida:

- Eubacterium limosum i altres de relacionades amb aquesta s'han trobat en concentracions deu vegades més grans en persones centenàries (Vaiserman, Koliada i Marotta, 2017).

- Akkermansia, Bifidobacterium i Christensenellaceae es van trobar augmentades en subjectes amb edats entre 105 i 109 anys (Biagi et al., 2016).

Cal tenir en consideració que, tal com apunten Vaiserman i els seus colllaboradors (Vaiserman, Koliada i Marotta, 2017), hi ha estudis que han trobat que la microbiota dels adults i de les persones de setanta anys és similar. En canvi, sí que hi ha diferències entre aquests subjectes i les persones centenàries. 
TAULA 2. RESUM DE LES MODIFICACIONS OBSERVADES EN LA MICROBIOTA DE POBLACIONS DE PERSONES CENTENÀRIES

\begin{tabular}{|c|c|c|c|c|}
\hline Firmicutes & Bacteroidetes & Proteobacteria & Actinobacteria & Verrucomicrobia \\
\hline $\begin{array}{l}\text { Classe: } \\
\text { Bacilli } \\
\text { Famílies: } \\
\text { Ruminococcaceae } \\
\text { Christensenellaceae } \\
\text { Gèneres: } \\
\text { Clostridium } \\
\text { Espècie: } \\
\text { Anaerotruncus } \\
\text { colihominis } \\
\text { Eubacterium } \\
\text { limosum }\end{array}$ & & 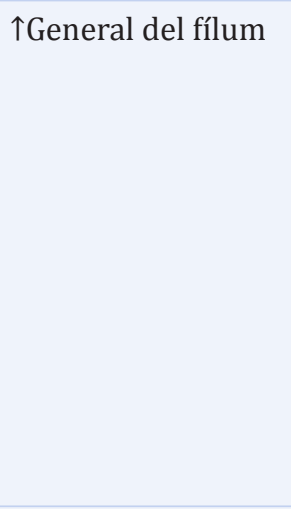 & $\begin{array}{l}\text { Gènere: } \\
\text { Bifidobacterium }\end{array}$ & $\begin{array}{l}\text { Gènere: } \\
\text { Akkermansia }\end{array}$ \\
\hline $\begin{array}{l}\text { Espècies: } \\
\text { Faecalibacterium } \\
\text { prausnitzii } \\
\text { Ruminococcus } \\
\text { obeum } \\
\text { Roseburia } \\
\text { intestinalis } \\
\text { Eubacterium } \\
\text { ventriosum } \\
\text { Eubacterium } \\
\text { rectale } \\
\text { Eubacterium Hallii } \\
\text { Papillibacter } \\
\text { cinnamovorans }\end{array}$ & $\begin{array}{l}\text { Gènere: } \\
\text { Bacteroides }\end{array}$ & $\begin{array}{l}\text { Família: } \\
\text { Enterobacteriaceae }\end{array}$ & $\begin{array}{l}\text { Gènere: } \\
\text { Bifidobacterium }\end{array}$ & \\
\hline
\end{tabular}

\subsection{Com condiciona la microbiota la salut d'aquests grups?}

Si s'observa la primera taula, la de la població amb edat avançada, es pot veure que augmenten els fílums Bacteroidetes i Proteobacteria. En aquests mateixos subjectes es veuen reduïdes les espècies amb potencial antiinflamatori, com ara Faecalibacterium prausnitzii i Eubacterium rectale (ambdues productores de butirat). També es veuen clarament reduïdes les espècies del gènere Bifidobacterium, les quals s'ha vist que són capaces d'inhibir la inflamació induïda per LPS (Riedel et al., 2006). Dins dels Firmicutes també s'observa la reducció del gènere Lactobacillus, el qual en ratolins es va observar que reduïa la inflamació i disminuïa els nivells de la citosina IL-8 (Pan et al., 2018).

Per altra banda, sembla que en les persones centenàries també s'observa un augment del fílum Proteobacteria. L'augment d'aquest fílum en els dos grups que es comparen s'ha relacionat amb un augment de les citosines a favor de la inflamació. Per exemple, en les persones centenàries es va observar que l'increment d'aquests bacteris, juntament amb una reducció dels bacteris productors de butirat, anava correlacionat positivament amb més presència d'IL-6 i IL-8 (Santoro et al., 2018)evolutionarily molded ecological system, which contributes to a variety of physiological functions. The GM is highly dynamic, being sensitive to environmental stimuli, and its composition changes over the host's entire lifespan. However, the basic question of how much these changes may be ascribed to variables such as population, diet, genetics and gender, and/or to the aging process per se is still largely unanswered. We argue that comparison among studies on centenarians-the best model of healthy aging and longevity-recruited from different geographical areas/populations (different genetics and dietary habits. Com s'explica, llavors, que les persones centenàries arribin a una longevitat 
tan extrema? Sembla que aquests individus mostren altres característiques que contraresten aquesta inflamació. Una de les hipòtesis estudia la remodelació del fílum Firmicutes en les persones centenàries. Tot i que es redueixen els bacteris amb efecte antiinflamatori, altres com Eubacterium limosum es veuen clarament augmentats. Per aquest motiu, E. limosum sembla tenir un paper molt important en l'elevada esperança de vida: és capaç de convertir isoflavonoides en fitoestrògens, coneguts, aquests darrers, pel seu paper protector en el desenvolupament de càncers i malalties coronàries (Biagi et al., 2010).

Per altra banda, les persones centenàries no presenten aquest augment tan clar de Bacteroidetes (de fet, s'ha observat una disminució del gènere Bacteroides), ni la davallada tan marcada de Firmicutes. Pel que fa als Firmicutes, s'hi observa també una reducció, a l'igual dels subjectes d'edat avançada, d'espècies productores de butirat. No obstant això, també hi ha evidència de l'augment d'altres espècies productores d'aquest àcid gras de cadena curta, com l'E. limosum o l'Anaerotruncus colihominis. Aquesta diferència és interessant perquè podria explicar el fet que les persones centenàries mantinguin una producció de butirat més alta respecte a les que viuen menys anys.

Vist això, es pot deduir que la reducció de la relació Firmicutes/Bacteroidetes serà més marcada en la gran majoria de gent, respecte a les persones centenàries. Segons Mariat i els seus collaboradors (Mariat et al., 2009), la relació Firmicutes/Bacteroidetes mostra diferències significatives entre els infants $(F / B=0,4)$ i els adults $(F / B=10,9)$, i entre els adults i els subjectes d'edat avançada $(\mathrm{F} / \mathrm{B}=0,6)($ Mariat et al., 2009). Per tant, aquesta davallada es pot relacionar amb l'envelliment, alhora que permet fer deduccions interessants sobre les persones centenàries, en les quals la relació no sembla disminuir tant.

A més, els estudis suggereixen una davallada important de Lactobacillus i Bifidobacterium en edat avançada. En canvi, aparentment en les persones centenàries això no està tan clar. Hi ha un treball interessant respecte a aquesta qüestió (Spaiser et al., 2015), en el qual s'estudia l'efecte en humans d'un probiòtic que conté Lactobacillus gasseri KS-13, Bifidobacterium bifidum G9-1 i Bifidobacterium longum MM-2. Els subjectes que es van estudiar eren d'edat avançada i es volia veure com el probiòtic afectava la concentració de limfòcits CD4+ i de citosines circulants. Es va observar que els individus que el van prendre van mantenir les concentracions de limfòcits CD4+ i també van mostrar un perfil de citosines inflamatòries menor (Spaiser et al., 2015). Com es pot observar a les taules, les persones centenàries no mostren aquesta davallada de Lactobacillus i Bifidobacterium tan marcada, i això es podria traduir en una millor conservació dels limfòcits CD4+ i una menor inflamació.

Una de les observacions més suggeridores és la de les espècies que s'han trobat clarament augmentades en poblacions de persones centenàries i que es creu que allarguen la vida. Per exemple, espècies de la família Christensenellaceae (molt típiques en la microbiota de persones que viuen molts anys) i del gènere Akkermansia (s'ha vist que modulen el sistema immunitari protegint enfront de la inflamació i promovent l'homeòstasi metabòlica) (Biagi et al., 2016).

Finalment, un factor que no es pot passar per alt és la variació de la microbiota en funció del lloc d'estudi. N'és un exemple una comparació que es va fer entre subjectes italians i subjectes xinesos (Santoro et al., 2018), tots ells d'extrema longevitat. S'hi van observar clares diferències en la microbiota, determinades per factors genètics, geogràfics i alimentaris. No obstant això, es va veure que en ambdós llocs la macrobiòtica estava enriquidaamb bacteris de les famílies Ruminococcaceae i Christensenellaceae, com també del gènere Akkermansia. Com s'acaba de veure, són espècies relacionades amb la modulació del sistema immunitari i l'homeòstasi metabòlica. A més a més, també mostren relació amb la massa corporal (Santoro et al., 2018).

\subsection{Es pot intervenir per modificar la microbiota?}

Com s'ha anat veient al llarg del treball, són diversos els factors que propicien els canvis de la microbiota amb l'edat. En són alguns exemples els problemes per mastegar, la pèrdua de dents, la reducció de l'activitat física, les variacions en l'estil de vida, les malalties, els antibiòtics, etc. Al seu torn, com 
bé s'ha comentat, els canvis en la composició bacteriana intestinal sovint promouen un augment de la inflamació crònica de baix grau i una reducció del potencial antiinflamatori. Això representa un factor de risc afegit que patiran les persones afectades per la gran majoria de malalties associades a l'edat. Consegüentment, és senzill entrar en un cercle viciós del qual és complicat sortir i amb el qual l'envelliment es veu accelerat.

Hi ha diferents opcions per modular la composició de la microbiota. Algunes de les estratègies utilitzades són intervencions dietètiques, exercici físic, transplantament fecal, prebiòtics i probiòtics. El treball se centra en aquesta última estratègia: els probiòtics.

Se n'han començat a veure diferents utilitats interessants, com, per exemple: el potencial antimicrobià, la millora de la funció de la barrera epitelial intestinal, l'efecte modulador del sistema immunitari (Buford, 2017) o la relació amb la producció de neurotransmissors (Vaiserman, Koliada i Marotta, 2017).

També s'ha demostrat que poden modificar la composició de la microbiota, atès que mostren propietats antiinflamatòries (Buford, 2017). A causa d'aquesta capacitat d'incidir en la composició de la microbiota en subjectes d'edat avançada, ja s'estan aplicant en patologies intestinals i respiratòries (Vaiserman, Koliada i Marotta, 2017).

Les soques de les quals consten més estudis són d'espècies dels gèneres Lactobacillus i Bifidobacterium. Per exemple, d'un probiòtic de Lactobacillus rhamnosus s'ha demostrat que promou vies antiinflamatòries en altres bacteris residents (Vaiserman, Koliada i Marotta, 2017), i Lactobacillus plantarum sembla que redueix l'envelliment a causa de la llum en humans (Vaiserman, Koliada i Marotta, 2017). També hi ha estudis de Lactobacillus brevis en ratolins, en els quals redueix la producció de LPS de la microbiota, l'expressió de p16 i l'activació de NF-kB (Vaiserman, Koliada i Marotta, 2017). Consegüentment, s'ha vist que els probiòtics augmenten la vida d'aquests animals (Vaiserman, Koliada i Marotta, 2017).

La revisió de Rondanelli i els seus colllaboradors (Rondanelli et al., 2015) recull tres estudis sobre probiòtics en persones d'edat avançada. En tots tres s'observa la variació de la microbiota, respecte al placebo, després de l'administració de complements probiòtics per via oral. A més a més, algunes de les espècies de les quals s'observa l'augment són dels gèneres Lactobacillus i Bifidobacterium. Aquests són els principals gèneres trobats en els complements probiòtics comercialitzats.

És important tenir en compte que les propietats dels probiòtics són específiques per a cada soca. Per tant, cal basar-se en estudis fets en soques concretes i evitar les extrapolacions (Mello et al., 2016).

De moment, els diferents estudis són prometedors, però és un tema relativament nou i encara és necessària més investigació. De la mateixa manera, tot i que per norma general els probiòtics estan mostrant un alt perfil de seguretat, hi ha certs grups de risc (Vaiserman, Koliada i Marotta, 2017), fet que també aconsella que és important fer més recerca.

\subsection{Probiòtics comercialitzats i inflamació}

Després de fer recerca sobre probiòtics comercialitzats, la realitat és que avui dia no es troben al mercat productes indicats especialment per a un envelliment saludable. Per contra, són més presents els productes orientats a prevenir o tractar patologies intestinals, entre d'altres. Cal tenir en compte que sovint aquestes malalties intestinals parteixen d'una disbiosi i d'un augment de la inflamació local i sistèmica.

És per això que s'ha buscat informació sobre dos productes molt implantats al mercat, dels quals es troben estudis publicats i que són indicats en les malalties inflamatòries intestinals. A partir d'aquí, es discutirà si aquests productes podrien ser indicats de cara a la població adulta per modular els canvis de la microbiota associats a l'edat $\mathrm{i}$, com s'ha vist, relacionats amb l'envelliment. 


\section{Lactibiane Tolérance ${ }^{\circledR}$}

L'estudi de Drouault-Holowacz i els seus colllaboradors d'aquest producte data del 2005 (DrouaultHolowacz et al., 2006)where major modifications of the intestinal microflora have been reported, there is an increasing interest in modulating the flora with probiotic products. This work addresses the anti-inflammatory potential of Lactibiane Tolérance, a probiotic dietary supplement (mixture of four strains. Sembla que el producte ha canviat lleugerament des d'aquell estudi pioner, però els resultats que es van obtenir eren interessants. La informació de la composició actual s'ha extret directament d'un envàs del producte. També és important saber que el laboratori PiLeJe assigna a les soques un nom comercial per tal de no donar a conèixer a la competència les soques que utilitzen.

TAULA 3. COMPARATIVA DE LES SOQUES DEL PRODUCTE ESTUDIAT EL 2005 RESPECTE AL PRODUCTE QUE ES TROBA COMERCIALITZAT AVUI DIA.

Producte estudiat el 2005 ( $4 \times 10^{9}$ UFC/càpsula) (Drouault-Holowacz et al., 2006)

\section{Producte actual (10x10 ${ }^{9}$ FC/càpsula)}

Bifidobacterium lactis LA 303

Bifidobacterium lactis LA 303

Lactobacillus acidophillus LA 201

Lactobacillus acidophillus LA 201

Lactobacillus plantarum LA 301

Lactobacillus plantarum LA 301

Lactobacillus salivarius LA 302

Lactobacillus salivarius LA 302

Bifidobacterium lactis LA 304

L'objectiu de l'estudi era conèixer l'efecte d'aquestes soques respecte a la malaltia infamatòria intestinal gràcies al seu potencial antiinflamatori (Drouault-Holowacz et al., 2006).

\section{Mètodes:}

- In vitro: s'estudiava l'alliberament de citosines per part de cèl-lules mononuclears de sang perifèrica, en contacte amb el preparat de bacteris. Es van quantificar els nivells de citosines IL-10 (antiinflamatòries) i IL-12 (a favor de la inflamació) mitjançant el mètode ELISA (Drouault-Holowacz et al., 2006).

- In vivo: es va fer en ratolins i estudiava l'efecte del complex probiòtic en induir la colitis mitjançant àcid trinitrobenzè sulfònic (TNBS). Dos dies després d'induir la colitis, es feia una valoració histològica del còlon dels ratolins (Drouault-Holowacz et al., 2006).

\section{Resultats:}

- In vitro: es va observar que les soques estudiades induïen la secreció de IL-10 i, en canvi, tenien poca capacitat per estimular la producció de IL-12 (Drouault-Holowacz et al., 2006).

- In vivo: es va demostrar que l'administració diària de $10^{8}$ bacteris de Lactibiane Tolérance ${ }^{\circledR}$ via oral reduïa significativament la colitis induïda per TNBS. Es va veure una menor lesió epitelial, menys pèrdua de cèl-lules caliciformes i de criptes, menys infiltrats inflamatoris i 
també un manteniment de la integritat de la paret intestinal, de manera similar a una persona sana (Drouault-Holowacz et al., 2006).

\section{Discussió:}

Tot i que la part in vitro d'aquest estudi es fa en cèllules humanes, es troben a faltar aspectes importants. Per exemple, no s'estudia la implantació de les soques en el tracte intestinal humà després de l'administració del probiòtic.

Amb les tècniques de seqüenciació actuals, seria convenient demostrar que realment el probiòtic modifica la composició de la microbiota. L'estudi d'aquest probiòtic en concret va ser pioner en el seu moment, l'any 2005, però actualment es tenen eines per fer estudis molt més acurats de cara a l'aplicació en humans.

Per altra banda, aquest producte es pot considerar atractiu respecte a la modulació de la inflamació sistèmica i l'envelliment associat. Conté soques dels gèneres Bifidobacterium i Lactobacillus, ambdues reduïdes en poblacions d'edat avançada. A més a més, s'ha demostrat que les soques de Bifidobacterium lactis tenen un efecte inhibidor de la inflamació induïda per LPS (Riedel et al., 2006).

Bifidobacterium i Lactobacillus són unes de les eines interessants en les intervencions per millorar la salut en gent d'edat avançada. Es relacionen amb l'activació de rutes antiinflamatòries dels microorganismes residents, estimulen la resposta immunitària innata, augmenten la resistència a l'estrès oxidatiu i modulen la senyalització de serotonina (Santoro et al., 2018). Per tant, es pot considerar un producte interessant a l'hora de recomanar-lo com a complement per a un envelliment saludable. No es pot oblidar que, com s'ha dit, són convenients més estudis mitjançant les tècniques de seqüenciació actuals.

\section{Vivomixx ${ }^{\circledR}$}

Es tracta d'un dels complements probiòtics amb més estudis del mercat. En un dels estudis (Gionchetti et al., 2000) s'ha vist que Vivomixx® mostra resultats molt positius en malalties intestinals, com ara la reservoritis crònica humana. A més a més, també es troben diferents estudis (Rincón et al., 2014; Dolpady et al., 2015; Ekmekciu et al., 2017), en animals i humans, on s'analitza l'efecte del producte en indicacions que van més enllà d'un àmbit intestinal local.

Per exemple, s'ha demostrat que en ratolins és capaç de modular la resposta immunitària innata i adaptativa, no només a nivell intestinal, sinó també a nivell perifèric (node limfàtic mesentèric) i central (melsa) (Ekmekciu et al., 2017). També en ratolins, s'ha relacionat amb beneficis en el control de la diabetis autoimmune (Dolpady et al., 2015). Fins i tot s'han observat beneficis cognitius en rates a les quals es va administrar aquest complement probiòtic (Rincón et al., 2014).

També hi ha alguns estudis en humans (Gionchetti et al., 2000; Rincón et al., 2014). Per exemple, en subjectes amb cirrosis o ascites, es va relacionar el complement probiòtic amb una millora de la patologia i amb un efecte potencial en el control de la hipertensió portal associada (Rincón et al., 2014).

A favor d'aquest complement probiòtic val a dir que sí que es troben estudis (Dolpady et al., 2015; Ekmekciu et al., 2017)alone or in combination with retinoic acid (RA on, a part dels beneficis clínics que s'observen, també s'estudien els canvis directes que tenen lloc en la composició de la microbiota dels ratolins. 
Edusfarm 11-12 (2019-2020), 153-170

ISSN: 1886-6271

\section{TAULA 4. COMPOSICIÓ DEL COMPLEMENT PROBIÒTIC VIVOMIXX®}

(Grifols SA, 2017)

\section{Vivomixx@(1,12x1011 UFC/càpsula)}

Bifidobacterium longum DSM 24736
Bifidobacterium infantis DSM 24737
Bifidobacterium breve DSM 24732
Lactobacillus acidophilus DSM 24735
Lactobacillus paracasei DSM 24733
Lactobacillus delbrueckii subsp. Bulgaricus DSM 24734
Lactobacillus plantarum DSM 24730
Streptococcus thermophilus DSM 24731

\section{Discussió:}

De manera similar al producte estudiat anterior, conté una gran quantitat de Lactobacillus i Bifidobacterium, altament associats a una microbiota sana i les proporcions dels quals disminueixen amb l'edat.

A més a més, el complement Vivomixx® també té Streptococcus thermophilus DSM 24731. Es va realitzar un estudi on es mirava el potencial antiinflamatori de diverses soques de Streptococcus thermofilus (Junjua et al., 2016). S'hi va observar que la majoria reduien la citosina a favor de la inflamació de IL-8 i induïen la producció de citosina IL-10 (antiinflamatòria), alhora que augmentava la proporció IL-10/IL-12 utilitzada per mesurar el potencial antiinflamatori. Cal tenir en compte que la resistència al pH àcid, a les sals biliars o la capacitat d'adhesió, varia de soca en soca. Al mateix temps, es desconeix si la soca present a Vivomixx® va ser de les estudiades en aquest experiment (Junjua et al., 2016), ja que possiblement també utilitza una nomenclatura pròpia, com fa el Lactibiane Tolérance®.

La gran quantitat d'estudis i els resultats obtinguts l'avalen com un gran candidat a recomanar-lo. A part de les indicacions en patologies intestinals i tractaments antibiòtics per les quals és àmpliament conegut, la seva indicació es considera coherent en gent d'edat avançada (o abans, per prevenir) per tal d'afavorir un envelliment saludable.

\subsection{Discussió final}

\section{Proposta de probiòtic ideal per a un envelliment saludable}

Sembla evident que la microbiota canvia amb l'edat i s'està veient la gran relació que aquest canvi té amb l'envelliment. Per contra, avui dia no es troben al mercat probiòtics indicats per a l'envelliment o com a preventius en edats més precoces.

També és important tenir en compte que alguns dels probiòtics comercialitzats podrien ser interessants, com s'ha vist, per a persones d'edat avançada. Molts d'ells estan formats sobretot per Lactobacillus i Bifidobacterium, gèneres que es veuen disminuïts amb l'edat i els quals aporten diferents beneficis ja comentats, com és el cas d'una menor inflamació sistèmica.

No obstant això, després d'analitzar en profunditat els canvis que tenen lloc, així com també les característiques diferencials de les persones centenàries, sembla possible pensar en probiòtics indicats especialment per a aquest grup de població. 
Una premissa important és no perdre de vista que la microbiota és un ecosistema molt complex, dinàmic i variat. Per aquest motiu, és arriscat aventurar-se a proposar un probiòtic amb soques específiques, sense estudiar prèviament com interaccionaran dins de l'hoste o quina serà la seva capacitat real de colonitzar-ne l'intestí. A més, gran part de les soques no són cultivables amb les eines de les quals es disposa actualment, fet que és un factor limitant en el desenvolupament de nous complements probiòtics.

Per tant, seguint amb l'objectiu de plantejar un probiòtic ideal per a un envelliment saludable i basant-nos en les pistes que donen les poblacions de persones centenàries, proposem investigar un complement que presenti les característiques següents:

- Espècies dels gèneres Lactobacillus i Bifidobacterium. Aquests gèneres disminueixen amb l'edat i ja s'ha vist que poden aportar beneficis importants en l'edat avançada. Curiosament, les persones centenàries no presenten tanta davallada d'aquests gèneres, fet indicatiu de la seva importància.

- Espècies productores de butirat: en edats avançades es redueixen les espècies capaces de produir-ne, cosa que fa reduir els beneficis antiinflamatoris i moduladors del sistema immunitari que aporta. Es proposa l'ús d'Eubacterium limosum, ja que produeix butirat i s'ha vist molt augmentat en persones centenàries. També Faecalibacterium prausnitzii, perquè a part de produir butirat, és un bon indicador de la salut intestinal i una espècie antiinflamatòria.

- Finalment, espècies dels gèneres que s'han vist augmentats en persones centenàries i que s'han relacionat amb una elevada esperança de vida: Akkermansia, Bifidobacterium i alguns de la família Christensenellaceae. Tot i que falten estudis respecte a aquesta qüestió, es planteja que poden tenir un paper clau en la microbiota en edat avançada.

A més a més, seria interessant realitzar estudis de seguiment en subjectes d'edat avançada que encara no són centenaris. Els estudis actuals observen la microbiota en persones que ja tenen més de cent anys, però quina microbiota tenien les persones centenàries quan eren més joves?

\section{Conclusions}

Les conclusions extretes del treball són les següents:

- Tot i la seva localització a l'intestí, la microbiota intestinal té un gran impacte a nivell sistèmic. Protegeix d'infeccions, participa en el metabolisme de nombroses reaccions i té un paper important en la inflamació sistèmica.

- La inflamació aguda és beneficiosa a nivell fisiològic en determinades situacions, però les persones d'edat avançada perden en part la capacitat de revertir aquesta inflamació i això dona lloc a un estat crònic d'inflamació sistèmica de baix grau.

- La inflamació sistèmica de baix grau accelera l'envelliment i és un factor de risc de la gran majoria de les malalties associades a l'edat.

- La composició de la microbiota intestinal és dinàmica i varia constantment des del naixement fins a la mort. En edats avançades es redueixen les espècies amb capacitat antiinflamatòria, alhora que sovint augmenten els bacteris patògens que fins ara restaven en poca proporció.

- La microbiota intestinal de persones en edat avançada difereix de la de les persones que viuen més de cent anys.

- Les persones centenàries presenten una menor reducció de Firmicutes i un menor augment de Bacteroidetes. No mostren una davallada tan marcada de Lactobacillus i Bifidobacterium. Hi ha poblacions de persones centenàries que mostren altes concentracions de bacteris 
concrets que s'han relacionat amb una elevada esperança de vida. L'augment d'algunes espècies productores de butirat, com ara Eubacterium limosum, sembla que hi té un paper clau.

- Intervencions dietètiques, exercici físic, probiòtics, prebiòtics i transplantament fecal són intervencions amb potencial per millorar la composició de la microbiota intestinal.

- Existeixen productes probiòtics ja comercialitzats al mercat, els quals es poden considerar atractius en la modulació de la microbiota intestinal en edat avançada.

Després de la realització d'aquest treball he proposat un possible probiòtic ideal per a un envelliment saludable, però la complexitat de la microbiota obliga a la realització de més estudis per poder extreure afirmacions concloents.

Opino fermament que tant la microbiota com la prevenció són dos temes d'actualitat i amb molt de potencial. Per tant, la futura investigació sobre microbiota intestinal, inflamació i envelliment sembla estar assegurada.

\section{Bibliografia}

BELKAID, Y., HAND, T.W. (2014) «Role of the Microbiota in Immunity and Inflammation». CELL, 157(1), p. 121-141. doi: 10.1016/j.cell.2014.03.011.

BIAGI, E. et al. (2010) «Through Ageing, and Beyond: Gut Microbiota and Inflammatory Status in Seniors and Centenarians». PLOS ONE, 5(5), p. e10667.

BiAGI, E. et al. (2016) «Gut Microbiota and Extreme Longevity». Current Biology (Elsevier Ltd.), 26(11), p. 1480-1485. doi: 10.1016/j.cub.2016.04.016.

BUFORD, T.W. (2017) «(Dis)Trust your gut: the gut microbiome in age-related inflammation, health, and disease». Microbiome, 5(80), p. 1-11. doi: 10.1186/s40168-017-0296-0.

Bischoff, S.C. (2016) «Microbiota and aging». Current Opinion in Clinical Nutrition and Metabolic Care, 19(1), p. 26-30. doi: 10.1097/mco.0000000000000242.

CALDER, P.C. et al. (2017) «Health relevance of the modification of low grade inflammation in ageing (inflammageing) and the role of nutrition». Ageing Research Reviews, 40, p. 95-119. doi: 10.1016/j. arr.2017.09.001.

CLAESSON, M.J. et al. (2012) «Gut microbiota composition correlates with diet and health in the elderly». Nature, 488, p. 178-185. doi: 10.1038/nature11319.

Clemente, J.C., MAnasson, J., Scher, J.U. (2018) «The role of the gut microbiome in systemic inflammatory disease». BMJ (Online), 360, p. j5145. doi: 10.1136/bmj.j5145.

DoLPADY, J. et al. (2015) «Oral probiotic VSL\#3 prevents autoimmune diabetes by modulating microbiota and promoting indoleamine 2,3-dioxygenase-enriched tolerogenic intestinal environment». Journal of Diabetes Research (Hindawi Publishing Corporation), 2016, p. 7569431. doi: 10.1155/2016/7569431.

Drouault-HolowaCZ, S. et al. (2006) «Anti-inflammatory potential of the probiotic dietary supplement Lactibiane Tolérance: In vitro and in vivo considerations». Clinical Nutrition, 25(6), p. 994-1003. doi: 10.1016/j.clnu.2006.03.006.

Eкмeкciu, I. et al. (2017) «The Probiotic Compound VSL\#3 Modulates Mucosal, Peripheral, and Systemic Immunity Following Murine Broad-Spectrum Antibiotic Treatment». Frontiers in Cellular and Infection Microbiology, 7(167), p. 1-19. doi: 10.3389/fcimb.2017.00167.

FRANCESCHI, C., CAMPISI, J. (2014) «Chronic inflammation (Inflammaging) and its potential contribution to age-associated diseases». Journals of Gerontology - Series A Biological Sciences and Medical Sciences, 69(S1), p. S4-S9. doi: 10.1093/gerona/glu057.

GionCHETTI, P. et al. (2000) «Oral bacteriotherapy as maintenance treatment in patients with chronic pouchitis: A double-blind, placebo-controlled trial». Gastroenterology, 119(2), p. 305-309. doi: 10.1053/ gast.2000.9370. 
GRIFols, SA (2017) Complemento alimenticio - Probiótico salud digestiva Vivomixx®, Sant Cugat del Vallès. Disponible a: www.vivomixx.es/es/home (últim accés: 10 desembre 2018).

VAn DE Guchte, M., Blottière, H.M., Doré, J. (2018) «Humans as holobionts: implications for prevention and therapy». Microbiome, 6(81), p. 1-6. doi: 10.1186/s40168-018-0466-8.

JefFery, I.B., Lynch, D.B., O'Toole, P.W. (2016) «Composition and temporal stability of the gut microbiota in older persons». The ISME Journal, 10, p. 170-182. doi: 10.1038/ismej.2015.88.

JunJuA, M. et al. (2016) «A large scale in vitro screening of Streptococcus thermophilus strains revealed strains with a high anti-inflammatory potential». LWT - Food Science and Technology, 70, p. 78-87. doi: 10.1016/j.lwt.2016.02.006.

Madigan, M.T. et al. (2015) Brock. Biología de los microorganismos. 14a ed. Ed. a cura de M. Martin-Romo. Madrid: Pearson Educación, SA.

MARIAT, D. et al. (2009) «The Firmicutes/Bacteroidetes ratio of the human microbiota changes with age». BMC Microbiology, 9(123), p. 1-6. doi: 10.1186/1471-2180-9-123.

Mello, A.M. et al. (2016) «Gastrointestinal Microbiota and Their Contribution to Healthy Aging». Digestive Diseases, 34(3), p. 194-201. doi: 10.1159/000443350.

Minciullo, P.L. et al. (2016) «Inflammaging and Anti-Inflammaging: The Role of Cytokines in Extreme Longevity». Archivum Immunologiae et Therapiae Experimentalis (Springer International Publishing), 64(2), p. 111-126. doi: 10.1007/s00005-015-0377-3.

O’Toole, P.W., JEFFERY, I.B. (2018) «Microbiome-health interactions in older people». Cellular and Molecular Life Sciences (Springer International Publishing), 75(1), p. 119-128. doi: 10.1007/s00018-0172673-z.

PAN, F. et al. (2018) «Predominant gut Lactobacillus murinus strain mediates anti-inflammaging effects in calorie-restricted mice». Microbiome, 6(54), p. 1-17. doi: 10.1186/s40168-018-0440-5.

RIEDEL, C.U. et al. (2006) «Anti-inflammatory effects of bifidobacteria by inhibition of LPS-induced NF- $\kappa \mathrm{B}$ activation». World Journal of Gastroenterology, 12(23), p. 3729-3735. doi: 10.3748/wjg.v12.i23.3729.

RINCón, D. et al. (2014) «Oral probiotic VSL\#3 attenuates the circulatory disturbances of patients with cirrhosis and ascites». Liver International, 34(10), p. 1504-1512. doi: 10.1111/liv.12539.

Robles-Alonso, V., GuARner, F. (2013) «Progreso en el conocimiento de la microbiota intestinal humana». Nutricion Hospitalaria, 28(3), p. 553-557. doi: 10.3305/nh.2013.28.3.6601.

RondANElli, M. et al. (2015) «Review on microbiota and effectiveness of probiotics use in older». World Journal of Clinical Cases (Baishideng Publishing Group Inc.), 3(2), p. 156-162. doi: 10.12998/wjcc. v3.i2.156.

SAntoro, A. et al. (2018) «Gut microbiota changes in the extreme decades of human life: a focus on centenarians». Cellular and Molecular Life Sciences (Springer International Publishing), 75(1), p. 129-148. doi: 10.1007/s00018-017-2674-y.

Sender, R., Fuchs, S., Milo, R. (2016) «Are We Really Vastly Outnumbered? Revisiting the Ratio of Bacterial to Host Cells in Humans». CELL, 164(3), p. 337-340. doi: 10.1016/j.cell.2016.01.013.

SPAISER, S.J. et al. (2015) «Lactobacillus gasseri KS-13, Bifidobacterium bifidum G9-1, and Bifidobacterium longum MM-2 Ingestion Induces a Less Inflammatory Cytokine Profile and a Potentially Beneficial Shift in Gut Microbiota in Older Adults: A Randomized, Double-Blind, Placebo-Con». Journal of the American College of Nutrition, 34(6), p. 459-469. doi: 10.1080/07315724.2014.983249.

Vaiserman, A.M., KoliadA, A.K., Marotta, F. (2017) «Gut microbiota: A player in aging and a target for anti-aging intervention». En: Ageing Research Reviews (Elsevier B.V.), 35, p. 36-45. doi: 10.1016/j. arr.2017.01.001.

YANG, X. et al. (2009) «More than 9,000,000 Unique Genes in Human Gut Bacterial Community : Estimating Gene Numbers Inside a Human Body». PLoSONE, 4(6), p. e6074.doi: 10.1371/journal.pone.0006074.

ZaPatA, H.J., QuAgliarello, V.J. (2015) «The Microbiota and Microbiome in Aging: Potential Implications in Health and Age-Related Diseases» Journal of the American Geriatrics Society. 63(4), p. 776-781. doi: $10.1111 /$ jgs.13310. 